\title{
REKRUTMEN DAN PENGEMBANGAN PNS DALAM PERSPEKTIF GOOD GOVERNANCE DI KABUPATEN LOMBOK TENGAH
}

\author{
Agus, M.Si \\ Email: aguschandra.lombok@gmail.com
}

\begin{abstract}
The purposes of this research are to describe; the condition of civil servants (PNS), the implementation of recruitment and development of civil servants, also problems and policy solutions for good governance practices in the recruitment and development of civil servants in Central Lombok. The result of research, there is surplus (excess) of the number of civil servants who have to occupy the position on Echelon III, those are 4,241 people and echelon II are 73 people. The implication is unhealthy competition to obtain structural positions, which then disturbs the health of bureaucratic organizations. Recruitment of civil servants is guided by Government Regulation (PP) No. 98 of 2000 which constructs six stages of work; planning, announcement, application, screening, appointment of CPNS up to appointment to be civil servant. The position of Regent as the officer of the regional staffing authority gives him authority in the appointment of echelon IV to Echelon II without any sides' consideration. As the result, practices of civil servant development policy create three conditions; the growth of spoils system practices, the improper use of the work of Baperjakat, and ultimately the practices disturb the independence of Baperjakat work. Good governance practice in civil servant recruitment has practiced aspects of efficiency, transparency and equity, but it has not been seen in the development aspect. Based on the above conditions, this research offers policy solutions to local governments.
\end{abstract}

Keywords: Good Governance, Policy, Recruitment, Civil Servant Development 


\section{A. Pendahuluan}

Tata pemerintahan yang baik atau good governanance sudah lama menjadi mimpi banyak orang di Indonesia. Kendati pemahaman tentang konsep ini masih beragam, namun sebagian ilmuan sosial parcaya bahwa dengan memasukkan nilai good governance dalam pemerintahan, Indonesia akan memiliki kualitas pemerintahan yang lebihbaik. Hematpeneliti, penyelidikan good governance pada bangsa yang majemuk seperti Indonesia lebih efektif jika dimulai dari pemerintah kabupaten/kota.

Referensi yuridis studi pemerintahan daerah kabupaten/kota pada waktu penelitian ini dilakukan merujuk pada Undang-Undang Nomor 32 tahun 2004 tentang Pemerintah Daerah dan Undang-Undang Nomor 33 tahun 2004 tentang Perimbangan Keuangan Antara Pemerintah Pusat dan Pemerintah Daerah. Keduanya merupakan satu paket kebijakan di bidang tata kelola pemerintahan yang memperbaharui sistem pemerintahan daerah di Indonesia. Di awal kehadirannya paket kebijakan ini memberi harapan bagi perbaikan kinerja birokrasi pemerintah daerah, minimal mempercepat terwujudnya kesejahteraan masyarakat melalui peningkatan pelayanan, pemberdayaan dan peran serta masyarakat, serta peningkatan daya saing daerah.

Semangat ini yang ditangkat dalam reformasi birokrasi dan tata kelola birokrasi Indonesia. Dan diletakkanlah konsep ini menjadi prioritas pertama dari 14 prioritas nasional Kabinet Indonesia Bersatu jilid II yang harus diselesaikan dalam kurun waktu 2010 - 2014. Semangat reformasi birokrasi ini diharapkan mampu membawa perubahan praktek tata kelola pemerintahan (pusat dan daerah) dengan indikasi keberhasilan sebagai berikut.

- Organisasi yang tepat fungsi dan tepat ukuran (right sizing).

- Sistem, proses dan prosedur kerja yang jelas, efektif, efisien,terukur dan sesuai dengan prinsip-prinsip good governance.

- Regulasi yang lebih tertib, tidak tumpang tindih dan kondusif.

- SDM aparatur yang berintegritas, netral, kompeten, capable, profesional, berkinerja tinggi dan sejahtera.

- Meningkatnya penyelenggaraan pemerintahan yang bersih dan bebas KKN.

- Meningkatnya kapasitas dan akuntabilitas kinerja birokrasi.

- Pelayanan prima sesuai kebutuhan dan harapan masyarakat.

- Birokrasi dengan integritas dan kinerja yang tinggi.

Sejalan dengan agenda dan prioritas nasional tersebut, semangat reformasi birokrasi instansi pemerintah yang diaturdalam Peraturan MenteriNegara Pendayagunaan Aparatur Negara Nomor PER/15/M.PAN/7/2008 tentang Pedoman Reformasi Birokrasi Instansi Pemerintah, seluruh instansi 
pemerintah pusat dan daerah melakukan pembenahan terhadap tiga aspek yaitu kelembagaan, ketatalaksanaan, dan sumber daya manusia.

Terkait dengan agenda nasional di atas, Pemerintah Daerah Lombok Tengah menempatkan tata kelola pemerintahan yang baik sebagai salah satu issu strategis kebijakan pemerintahannya (dikutip dari; dokumen KPU Kabupaten Lombok Tengah tahun 2010). Terdapat lima program pokok untuk melaksanakan kebijakan tersebut, yakni; (1) pendayagunaan aparatur pemerintah dengan memperhatikan MSDM (management sumberdaya manusia) sesuai asas profesionalisme yang objektif dan berkeadilan, (2) peningkatan kapasitas dan penegakan disiplin aparatur pemerintah, (3) penyusunan pola pengembangan karir berdasarkan kompetensi dengan penilian berbasis kinerja, (4) peningkatan koordinasi dan integrasi dalam penyusunan maupun perencanaan program serta penganggaran yang berbasis kinerja, (5) penerapan transparansi dengan penerapan IT (informasi teknologi), pelaksanaan fakta integritas dan kontrak kerja pelayanan masyarakat.

Berdasarkan uraian di atas, penelitian ini secara berurutan menjawab permasalahan berikut; kondisi PNS, sistem rekrutmen dan pengembangan PNS, praktek good governance, permasalahan dan solusi kebijakan rekrutmen dan pengembangan PNS. Untuk kedalaman penyelidikan, penelitian ini mengambil kasus di Kabupaten Lombok Tengah.

\section{B. Kajian Pustaka}

\section{Prinsip Good Governance}

Untuk kepentingan penelitian ini, referensi good governance merujuk pada studi Dwiyanto (2008). Ia mengutip delapan prinsip good governance yang diperkenalkan oleh UNDP (United Nation Development Program), yaitu; partisipasi, transparansi, akuntabel, efektif dan efisiensi, kepastian hukum, responsif, konsensus, setara dan inklusif.

Dwiyanto selanjutnya mengembangkan delapan prinsip di atas menjadi sepuluh dengan penjelasan sebagai berikut:

a. Partisipasi, warga memiliki hak (dan mempergunakannya) untuk menyampaikan pendapat, bersuara dalam proses perumusan kebijakan publik, baik secara langsung maupun tidak langsung;

b. Penegakan hukum; hukum diberlakukan bagi siapapun tanpa pengecualian, hak asasi manusia dilindungi, sambil tetap memperhatikan nilai-nilai yang hidup dalam masyarakat;

c. Transparansi; penyediaaninformasi tentang pemerintah(an) bagi publik dan dijaminnya kemudahan di dalam memperoleh informasi yang akurat dan memadai; 
d. Kesetaraan; adanya peluang yang sama bagi setiap anggota masyarakat untuk beraktivitas/ berusaha;

e. Daya tanggap; pekanya para pengelola instansi publik terhadap aspirasi masyarakat;

f. Wawasan ke depan; pengelolaan masyarakat hendaknya dimulai dengan visi, misi, dan strategi yang jelas;

g. Akuntabilitas; pertanggungjawaban para penentu kebijakan kepada para warga;

h. Pengawasan publik; terlibatnya warga dalam mengontrol kegiatan pemerintah, termasuk parlemen;

i. Efektivitas dan efisiensi; terselenggaranya kegiatan instansi publik dengan menggunakan sumber daya yang tersedia secara optimal dan bertanggungjawab. Indikatornya antara lain; pelayanan mudah, cepat, tepat, dan murah;

j. Profesionalisme; tingginya kemampuan moral para pegawai pemerintah, termasuk parlemen.

Berdasarkan pemikiran di atas, peneliti merumuskan konsep good governance sebagai vitamin yang harus disuntikkan kepada setiap penyelenggaraan fungsi-fungsi negara. Sebagai vitamin, sudah barang tentu good governance dalam jangka panjang akan menghasilkan organisasasi publik yang sehat, dengan kesehatannya tersebut tentu akan menjadi modal utama dalam peningkatan produk kebijakan publik maupun pelayanan publik.

\section{Birokrasi Publik}

Syafi'i (2003), menjelaskan dari sisi bahasa, birokrasi dijelaskan sebagai berikut; dalam bahas Inggris birokrasi disebut bureauracy, berasal dari kata bureau (berarti meja) dan cratein (berarti kekuasaan), sehingga menjadi kekuasaan berada pada orang-orang yang dibelakang meja. Karena itu birokrasi dipahami sebagai pekerjaan yang dilaksanakan dari meja yang satu ke meja berikutnya.

Salah satu tokoh Sosiologi klasik, yakni Max Weber (1946) menyebutkan terdapat lima prinsip birokrasi, yakni:

a. Prinsip yurisdiksional, adalah prinsip yang menjadi kaedah atau ketentuan administratif kepegawaian modern, yaitu;

- Aktivitas reguler yang diperlukan bagi tujuan-tujuan struktur yang di atur secara birokratis didistribusikan dalam sebuah cara tertentu sebagai tugas-tugas resmi;

- Otoritas untuk memberikan perintah yang dibutuhkan untuk menjalankan tugas-tugas tersebut didistribusikan dalam suatu cara yang tetap dan sangat dibatasi oleh peraturanperaturan mengenai alatalat pemaksaan fisik, secara keagamaan atau lainnya, yang dipunyai oleh para pegawai; 
- Perangkat metodis dibuat bagi pemenuhan reguler dan berkelanjutan tugas-tugas tersebut dan bagi pelaksanaan hak-hak terkait; hanya orang yang mempunyai kualifikasi (yang ditentukan secara umum) untuk bertugas saja yang dipekerjakan.

b. Prinsip hirarkhi jabatan dan tingkat kewenangan berjenjang, adalah prinsip yang menunjukkan sebuah sistem supraordinasi dan subordinasi yang tertata rapi; dimana berlaku pengawasan terhadap jabatan yang lebih rendah oleh jabatan yang lebih tinggi. Dengan adanya perkembangan penuh tipe birokratis, maka hirarki jabatan pun diorganisasikan secara monarkis. Ketika prinsip "kompetensi" yurisdiksional didasarkan sepenuhnya, subordinasi hirarkhis tidak berarti bahwa otoritas lebih tinggi diberi kewenangan begitu saja untuk mengambil alih urusan-urusan rendah, tetapi yang berlaku justru sebaliknya.

c. Manajemen jabatan modern didasarkan pada dokumendokumen tertulis (berkas), yang disimpan dalam bentuk aslinya atau draft. Karena itu diperlukan staf pegawai rendahan dan segala macam juru tulis. Sekumpulan pegawai yang terlibat aktif dalam jabatn publik berikut aparat pelaksana material masingmasing dan berkas-berkasnya memunculkan sebuah biro atau kantor.

c. Prinsip manajemen jabatan yang terspesialisasi, yaitu jabatan yang diisi berdasarkan pelatihan dan keahlian.

d. Ketika jabatan sudah sepenuhnya dikembangkan, aktivitas resmi menuntut kapasitas kerja penuh waktu pegawai, tanpa mengindahkan fakta bahwa waktu wajibnya di biro mungkin sangat terbatas. Maka urusan resmi terkadang dilaksanakan sebagai aktivitas sekunder.

e. Manajemen jabatan mengikuti aturan-aturan umum, yang sedikit banyaknya stabil, menyeluruh dan bisa dipelajari. Pengetahuan tentang aturan-aturan itu merepresentasikan sebuah pembelajaran teknis khusus yang dikuasai para pegawai.

Said (2007) berusaha mendudukkan perbedaan birokrasi publik dan privat. Ia menyebutkan "berbeda dengan birokrsi privat atau bisnis yang menempatkan konsep birokrasi diarahkan untuk efisiensi pemakaian sumberdaya dengan penciptaan outputs dan keuntungan optimum, birokrasi di bidang organisasi publik dimaknai sebagai proses dan sistem yang diciptakan secara rasional untuk menjamin mekanisme dan sistem kerja yang teratur, pasti, dan mudah dikendalikan.

Meskipundemikian, dariprespektif manajemen SDM sektor privat dan 
sektor publik, memiliki persamaan tujuan yakni agar pegawai mampu memberikan pelayanan terbaik kepada masyarakat. Karena itulah Undang-Undang Nomor 43 tahun 1999 sebagai pengganti UndangUndang Nomor 8 tahun 1974 tentang Pokok-Pokok Kepegawaian memberi perubahan mendasar dalam sistim manajemen kepegawaian. Dalam ketentuan undang-undang tersebut, profesionalisme dalam pembinaan karir PNS dilaksanakan atas dasar perpaduan antara sistem prestasi kerja dan karir yang ditiikberatkan pada sistim prestasi kerja. Dengan demikian, terbuka peluang bagi PNS yang berprestasi tinggi untuk meningkatkan kemampuannya secara profesional dan berkompetisi secara sehat. Pengangkatan dalam jabatan didasarkan atas penilaian prestasi kerja yang obyektif, kompetensi, dan pelatihan-pendidikan yang bersangkutan (Wasistiono, 2002).

\section{Pola rekrutmen dan pengem- bangan pegawai}

Wasistiono (2002) mendefinisikan rekrutmen sebagai upaya untuk mendapatkan calon pegawai yang dibutuhkan organisasi atau dengan kata lain untuk mendapatkan dan menemukan pelamar yang qualified dengancaramengiklankanpenerimaan calon pegawai di suatu organisasi melalui media massa maupun media elektronik. Definisi yang dipaparkan Wasistiono di atas menegaskan bahwa rekrutmen pegawai dilakukan karena adanya kebutuhan organisasi akan tenaga kerja/karyawan atau untuk mengisi jabatan-jabatan yang masih kosong. Rumusan ini dapat pula dimaknai bahwa rekrutmen pegawai tidak mesti dilakukan apabila kebutuhan organisasi akan pegawai/ karyawan sudah terpenuhi dan tidak ada jabatan yang kosong dalam beberapa tahun kedepan.

Oleh karena itu Wasistiono menegaskan sebelum dilaksanakan rekrutmen terlebih dahulu dilaksanakan tahapan yang disebut Job Analisis atau analisis pekerjaan, yaitu menganalisa jenis pekerjaan yang harus dilakukan oleh organisasi sehingga tujuan organisasi dapat dicapai. Hasil Job Analisis adalah deskripsi tentang macam-macam pekerjaan yang dilakukan organisasi. Dari deskripsi ini ditemukan kriteria atau persyaratan yang harus dipenuhi, baik tenaga yang dibutuhkan maupun ruang dan peralatannya. Berdasarkan kriteria masing-masing pekerjaan tersebut dilakukan Analisa Kebutuhan Pegawai yang sesuai dengan pekerjaan dalam organisasi tersebut. Dari hasil analisa kebutuhan pegawai akan diperoleh gambaran formasi yang memungkinkan untuk diisi dengan tenaga kerja yang sesuai dengan jenis, sifat dan beban kerja yang harus dilaksanakan. Setelah mengetahui formasi kepegawaian maka dilakukanlah rekrutmen.

Dalam kaitan dengan pengembangan pegawai Situmorang (dikutip dalam Wasistiono, 2002) menyebutkan 
reorientasi manajemen kepegawaian terfokus pada optimalisasi SDM yang ahli, terampil dan profesional, yang mengedepankan:

a. Tenaga-tenaga yang mampu dalam melakukan job analysis (analisa pekerjaan). Analisa ini memiliki urgensi terhadap masukan (input) dalam bidang perencanaan akan kebutuhan pegawai. Dengan melakukan analisa pekerjaan tersebut setiap instansi akan dapat merencanakan kebutuhan nyata berdasarkan beban kerja yang menjadi tanggung jawab satuan unit kerja yang ada;

b. Tenaga-tenaga yang mampu melakukan analisa untuk kinerja pegawai yang akan dihubungkan dengan imbal jasa (reward) atas pelaksanaan tugas yang dilakukan. Analisa terhadap kinerja ini tidak hanya secara individual, tetapi juga secara kelompok;

c. Tenaga-tenaga terampil yang mampu melakukan pengukuran baik terhadap analisa kebutuhan pegawai, analisa pekerjaan, uraian pekerjaan, analisa jabatan, kinerja pegawai, imbal jasa pegawai, disertai dengan tolok ukurnya;

d. Tenaga-tenaga yang mempunyai keahlian ganda (multi skiled), dalam hal ini lulusan perguruan tinggi yang tidak hanya mempunyai satu keahlian saja.

\section{Metode Penelitian}

Seiring dengan topik yang dibahas, penelitian ini menggunakan pendekatan kualitatif, karena itu sesuai sifatnya sebagaimana dikemukakan Sugiyono (2011:205) masalah dalam rancangan berkembang dilapangan. Maksud peneliti menggunakan pendekatan ini agar peneliti mampu melepaskan apa yang telah difikirkan sebelumnya, dan selanjutnya mampu melihat fenomena secara lebih luas dan mendalami sesuai dengan apa yang terjadi dan berkembang pada situasi sosial yang diteliti. Disamping itu, metode ini diyakini mampu menemukan dan menguji kebenaran suatu pengetahuan sebagaimana disebutkan Nawawi (2007 : 26).

Dalam operesional pengumpulan data, penelitian ini tidak menggunakan istilah populasi melainkan social situation (situasi sosial) yang terdiri dari tiga elemen, yakni; tempat (place), aktor (actor), dan aktivitas (activity). Gejala dalam penelitian ini dilihat secara holistik (menyeluruh, tidak dipisah-pisah), maka peneliti tidak menetapkan penelitiannya hanya berdasarkan variabel penelitian, melainkan melihat seluruh situasi sosial yang diteliti. Keseluruhan situasi sosial tersebut adalah;

1. Tempat (place), yakni lembagalembaga yang terlibat dalam proses rekrutmen dan pengembangan pegawai negeri sipil, yakni; Badan Kepegawaian 
Daerah, dan Sekretariat lewat orang lain atau dokumen. Daerah.

Analisis data dalam penelitian ini

2. Aktor (actor), yakni; Bupati dan Wakil Bupati, Sekretaris Daerah, Kepala BKD dan pejabat terkait, para PNS.

3. Aktivitas (activity), yakni proses pelaksanaan rekrutmen dan pengembanganPNSKabupaten Lombok Tengah

Sebagaimana penelitian kualitatif lainnya, penelitian ini menjadikan peneliti berperan langsung selaku instrumen penelitian. Sedangkan pengumpulan data dengan beberapa teknik, yakni; dokumentasi, wawancara, observasi. Adapun sumber data yang dikumpulkan dikelompokkan menjadi dua kategori, yakni primer atau yang langsung dikumpulkan oleh peneliti mealui wawancara dan observasi, serta data sekunder atau data yang dikumpulakn dilakukan dengan tiga tahap yakni; data reduction (reduksi data), data display (penyajian data), dan conclusion drawing/verification.

\section{Hasil Penelitian}

\section{Kondisi PNS Kabupaten Lombok Tengah}

Konsekuensiketerbatasanlapangan kerja, PNS menjadi pilihan kerja paling dominan. Akibatnya, jumlah PNS daerah menjadi cukup tinggi dan birokrasi menjadi pelaku dominan dalam urusan publik. Gambaran jumlah PNS Lombok Tengah sebagai berikut:

a. Berdasarkan Golongan

Berdasarkan tingkat golongan jumlah PNS sebagaimana tampak pada tabel di bawah ini

Tabel 1 :

Jumlah PNS Kabupaten Lombok Tengah Berdasarkan Golongan

\begin{tabular}{|c|c|c|c|c|c|c|c|c|c|c|c|c|c|c|c|c|}
\hline \multicolumn{4}{|c|}{ Golongan I } & \multicolumn{4}{c|}{ Golongan II } & \multicolumn{4}{c|}{ Golongan III } & \multicolumn{4}{c|}{ Golongan IV } & Jumlah \\
\hline A & B & C & D & A & B & C & D & A & B & C & D & a & B & C & d & \\
\hline 28 & 54 & 79 & 55 & 713 & 902 & 763 & 381 & 128 & 129 & 910 & 1.276 & 3.265 & 88 & 15 & 0 & 11.107 \\
\hline
\end{tabular}

Sumber : Badan Kepegawaian Daerah Kabupaten Lombok Tengah, 2011 diolah.

Data di atas mendeskripsikan; jumlah pegawai tertinggi terdapat pada golongan IV/a mencapai 3.265 orang, diikuti oleh golongan III/d 1.276 orang, golongan III/b 1.294 orang, golongan III/a 1.284 orang, golongan III/c 910 orang, golongan II/b 902 orang, golongan II/c 763 orang, golongan II/a 713 orang, golongan II/d 381 orang, golongan IV / b 88 orang, golongan I/ c 79 orang, golongan I/d 55 orang, golongan I/b 54 orang, golongan IV/a 28 orang, dan yang paling kecil golongan IV/c 15 orang. 
Menurut keterangan dari beberapa informan penelitian, kondisi PNS yang demikian berakibat pada persoalan; golongan/pangkat tidak proporsional, persaingan jabatan yang tinggi, terganggunya kesehatan organisasi, sampaipadatidakprofesionalnyasistem penempatan pejabat struktural,

b. Berdasarkan Pendidikan

- Dari sisi pendidikan, jumlah pegawai Kabupaten Lombok Tengah digambarkan melalui tabel di bawah ini.

Tabel. 2:

Jumlah Pegawai Negeri Sipil Kabupaten Lombok Tengah

Berdasarkan Tingkat Pendidikan

\begin{tabular}{|c|c|c|c|}
\hline NO & PENDIDIKAN & JUMLAH & $\%$ \\
\hline 1. & SD & 117 & 1,00 \\
2. & SLTP & 225 & 2,02 \\
3. & SLTA & 2.507 & 22,57 \\
4. & D1 & 112 & 1,09 \\
5. & D2 & 2.920 & 26,28 \\
6. & D3 & 826 & 7,43 \\
7. & D4/S1 & 4.237 & 38,15 \\
8. & S2 & 0 & 1,46 \\
9. & S3 & 163 & 0 \\
\hline & Jumlah & 11.107 & 100 \\
\hline
\end{tabular}

Sumber : BKD Kabupaten Lombok Tengah 2011(diolah).

Tabel di atas menjelaskan kualitas Sumber Daya Manusia (SDM) pegawai dari sisi pendidikan formal belum baik karena meskipun pendidikan D4 dan S1 memiliki peringkat tertinggi $(38,15$ $\%$ ), namun yang berpendidikan SLTA dan D2 masih mencapai angka 22,57 $\%$ dan $26,28 \%$. Sedangkan pendidikan yang dipandang memiliki kemampuan analisis dan perencanaan yang baik untuk peningkatan pelayanan publik adalah berpendidikan S2. Kedua jenjang pendidikan tersebut masih sangat rendah, yakni S1 sebanyak 1,46 $\%$, dan pegawai berpendidikan S3 belum ada atau $0 \%$.

Dengan kondisi surplus di atas, mudah dikatakan bahwa formasi PNS
Kabupaten Lombok Tengah belum memenuhi kriteria proporsionalitas dan kualitas. Pada sisi yang lain beberapa kantor masih kekurangan tenaga teknis, seperti pramusaji dan tenaga kebersihan, karena rekrutmen PNS berorientasi pada golongan III/a. Sedangkan pendidikan formal pegawai sebagai ukuran profesionalisme pegawai, nyatanya belum baik.

\section{Sistem Rekrutmen}

Sistem rekrutmen PNS di atur dalamPeraturan Pemerintah Nomor 98 tahun 2000 tentang Pengadaan Pegawai Negeri Sipil. Pada bagian penjelasan dari peraturan ini disebutkan bahwa pengadaan PNS adalah proses kegiatan untuk mengisi formasi yang lowong. 
Lowongan formasi dalam suatu satuan organisasi Negara pada umumnya disebabkan adanya PNS yang berhenti, meninggal dunia, mutasi jabatan dan adanya pengembangan organisasi. Oleh karena pengadaan PNS adalah untuk mengisi formasi yang lowong, maka pengadaan dilaksanakan atas dasar kebutuhan, baik dalam arti jumlah dan mutu pegawai, maupun kompetensi jabatan yang diperlukan. Hal ini ditegaskan dalam Pasal 1 Peraturan Pemerintah Nomor 98 tahun 2000 mendefinisikan pengadaan Pegawai Negeri Sipil adalah "kegiatan untuk mengisi formasi yang lowong"

Sehubungan dengan hal di atas, setiap Warga Negara Indonesia yang memenuhi syarat berdasarkan ketentuan Peraturan Perundangundangan mempunyai kesempatan yang sama untuk melamar dan diangkat menjadi PNS. Makna dari rumusan konsep ini adalah pengadaan PNS harus didasarkan atas kebutuhan dan dilakukan secara obyektif sesuai dengan syarat yang ditentukan.

Pengadaan PNS menurut ketententuan peraturan di atas dilaksanakan dalam 6 (enam) tahapan, yakni; perencanaan, pengumuman, pelamaran, penyaringan, pengangkatan Calon Pegawai Negeri Sipil sampai dengan pengangkatan menjadi Pegawai Negeri Sipil (sumber ; Pasal 2 Ayat 1 Peraturan Pemerintah Nomor 98 tahun 2000).

Proses pengadaan PNS adalah pekerjaan yang bersifat siklus berdasarkan kebutuhan sebagaimana tampak pada gambar di bawah:

Gambar 1. Siklus Pengadaan PNS

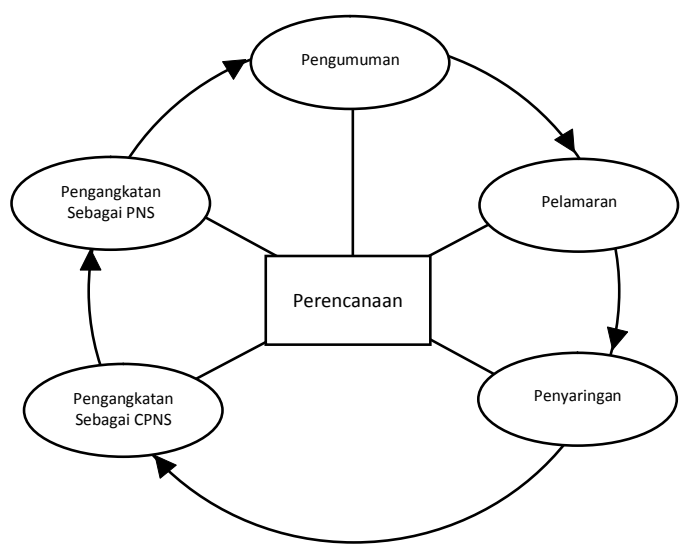

(Sumber : Peraturan Pemerintah Nomor 98 Tahun 2000, diolah)

Yang dimaksud dengan perencanaan pengadaan PNS adalah penjadwalan kegiatan yang dimulai dari inventarisasi lowongan jabatan yang telah ditetapkan dalam formasi beserta syarat jabatannya, pengumuman, pelamaran, penyaringaan, pengangkatan menjadi Calon Pegawai Negeri Sipil (CPNS) sampai dengan pengangkatan menjadi PNS.

Perencanaan pengadaan pegawai dilaksanakan oleh Pejabat Pembina Kepegawaian. Adapun yang dimaksud pejabat pembina kepegawaian adalah Menteri, Jaksa Agung, Sekretaris Negara, Sekretaris Kabinet, Sekretaris Militer, Sekretaris Presiden, Sekretaris Wakil Presiden, Kepala Kepolisian Negara, Pimpinan Kesekretariatan Lembaga Tertinggi/Tinggi Negara, Gubernur dan Bupati/Walikota.

Pengumuman ini dilaksanakan paling lambat 15 hari sebelum masa 
penerimaan berkas. Syarat yang harus dipenuhi oleh setiap pelamar adalah:

a. Warga Negara Indonesia;

b. Berusia serendah-rendahnya 18 (delapan belas) tahun dan setinggitingginya 35 (tiga puluh lima) tahun;

c. Tidakpernah dihukumpenjara atau kurungan berdasarkan keputusan pengendalian yang sudah mempunyai kekuatan hukum yang tetap, karena melakukan suatu tindak pidana kejahatan;

d. Tidakpernahdiberhentikandengan hormat tidak atas permintaan sendiri atau tidak dengan hormat sebagai Pegawai Negeri Sipil, atau diberhentikan tidak dengan hormat sebagai pegawai swasta;

e. Tidak berkedudukan sebagai Calon/ Pegawai Negeri;

f. Mempunyai pendidikan, kecakapan, keahlian dan ketrampilan yang diperlukan;

g. Berkelakuan baik;

h. Sehat jasmani dan rohani;

i. Bersedia ditempatkan di Seluruh wilayah Negara Republik Indonesia atau negara lain yang ditentukan oleh Pemerintah; dan

j. Syarat lain yang ditentukan dalam persyaratan jabatan (Sumber : pasal 6 Peraturan Pemerintah Nomor 98 tahun 2000)

Pelamar yang dinyatakan lulus administrasi selanjutnya mengikuti ujian yang diselenggarakan oleh panitia. Materi ujian meliputi; test kompetensi dan psikotest. Selanjutnya pelamar yang dinyatakan lulus ujian penyaringan diwajibkan menyerahkan kelengkapan administrasi sesuai ketentuan yang berlaku. Daftar pelamar yang dinyatakan lulus ujian penyaringan tersebut diangkat menjadi CPNS yang disampaikan oleh Pejabat Pembina Kepegawaian kepada Kepala Badan Kepegawaian Negara untuk mendapat nomor identitas PNS. Penyampaian daftar tersebut dilengkapi data perorangan sesuai dengan persyaratan yang ditentukan.

Setelah disetujui oleh Badan Kepegawaian Negara, pelamar tersebut diangkat menjadi CPNS dengan keputusan Pejabat Pembina Kepegawaian.Pengangkatandilakukan dalam tahun anggaran berjalan, dan penetapannya tidak boleh berlaku surut. Adapun golongan ruang yang ditetapkan untuk pengangkatan sebagai CPNS, adalah :

a. Golongan ruang I/a bagi yang pada saat melamar serendah-rendahnya memiliki dan menggunakan Surat Tanda Tamat Belajar./ Ijazah Sekolah Dasar atau yang setingkat;

b. Golongan ruang I/e bagi yang pada saat melamar serendah-rendahnya memiliki dan menggunakan Surat Tanda Tamat Belajar/Ijazah Sekolah Lanjutan Tingkat Pertama atau yang setingkat;

c. Golongan melamar serendah-rendahnya mimiliki dan 
menggunakan Ijazah Sarjana (S1), atau Diploma IV;

g. GolonganruangIII/bbagiyangpada saat melamar serendah-rendahnya memiliki dan menggunakan Ijazah Dokter, Ijazah Apoteker dan Ijazah lain yang setara, Magister (S2), atau Ijazah Spesialis I;

h. Golongan ruang III/c bagi yang pada saat melamar serendahrendahnya memiliki dan menggunakan Ijazah Doktor (S3), atau Ijazah Spesialis II.

(Sumber : Wawancara dengan Sekretaris BKD Kabupaten Lombok Tengah)

Rekrutmen PNS di Kabupaten Lombok Tengah sejak dua tahun terakhir telah menghilangkan penerimaan untuk golongan I dan mulai mengurangi penerimaan untuk golongan II. Penerimaan untuk golongan II hanya diperuntukan bagi formasi sopir dan tenaga kebersihan. Penerimaan pegawai didominasi oleh formasi golongan III/a, sedangkan III/b sampai penetian ini dilaksanakan belum pernah dilakukan oleh Pemerintah Kabupaten Lombok Tengah.

\section{Sistem Pengembangan}

Kebijakan pengembangan PNS Kabupaten Lombok Tengah mengacu pada Peraturan Pemerintah Nomor 96 tahun 2000 tentang wewenang pengangkatan, pemindahan, dan pemberhentian PNS. Produk kebijakan tersebut memberi kewenangan penuh kepada Bupati sebagai pejabat pemibina PNS untuk mengangkat, memindahkan, bahkan memberhentikan PNS daerah. Terdapat dua pasal yang memberi kewenangan tersebut, yakni:

1. Pasal 12 ayat (1) huruf c, menyebutkan " pejabat pembina kepegawaian daerah menetapkan pengangkatan, pemindahan, dan pemberhentian pegawai negeri sipil daerah kabupaten/kota dalam dan dari jabatan eselon II (dua) ke bawah atau jabatan fungsional".

2. Pasal 18 ayat (1), menyebutkan: "pejabat pembina kepegawaian daerah kabupaten/kota menetapkan:

a. Pemberhentian sementara Sekretaris Daerah kabupaten/ kota

b. Pemberhentian sementara dari jabatan negeri bagi pegawai negeri sipil daerah kabupaten/ kota yang menduduki jabatan struktural eselon II (dua) ke bawah atau jabatan fungsional"

Ketentuan kedua pasal di atas memberikan otoritas yang sangat tinggi (power full) kepada Bupati selaku pejabat pembina kepegawian daerah. Dengan ketentuan tersebut PNS Kabupaten Lombok Tengah memiliki loyalitas penuh terhadap Bupati. Dua bentuk paling fenomenal loyalitas yang ditunjukkan oleh pegawai kepada Bupati yakni; keterlibatan dalam pemenangan pemilukada dan kontribusi finansial kepada Bupati 
yang biasanya diambilkan dari realisasi anggaran

Kewenangan Bupati yang diberikan peraturan perundangundangan dan loyalitas pegewai yang digambarkan di atas, mempengaruhi tiga fenomena pengembangan PNS, yakni; suburnya praktek spoils system (sistem pertemanan), subjektifitas Bupati dalam penentuan pejabat, dan terganggunya indevendensi Badan Pertimbangan Jabatan dan Kepangkatan (Baperjakat).

\section{Praktek Good Governance Dalam Rekrutmen dan Pengembangan PNS}

\section{a. Efisiensi}

Efisien didefinisikan sebagai perbandingan terbaik antara input dan output (Dwiyanto, 2008 ; 157). Yang dimaksud input adalah biaya, waktu, dan tenaga. Dari sisi input dikatakan efisien apabila kegiatan tersebut menggunakan sumber daya yang murah dan tidak boros. Dari sisi proses dikatakan efisien apabila prosuduryang dilakukan bersifat sederhana, sehingga warga pendaftar tidak mengeluarkan energi dan biaya dalam mengakses suatu layanan. Sedangkan dari sisi output dikatakan efisien apabila dengan biaya yang murah dan tidak boros tadi tetap menghasilkan produk yang sesuai dengan standar dan dapat memuaskan pengguna layanan.

Dari sisi proses rekrutmen PNS di Kabupaten Lombok Tengah, telah memperhatikan asas efisiensi. Hal ini terlihat dari perubahan beberapa persyaratan dan penerimaan berkas. Apabila pada rekrutmen pegawai terdahulu, pelamar diharuskan melampirkan seluruh persyaratan administrasi yang dipersyaratkan undang-undang, maka pada rekrutmen di dua tahun terakhir (2009 dan 2010) pelamar hanya diminta menyerahkan; surat lamaran, foto copy ijazah yang dilegalisir, pas photo, dan foto copy KTP yang telah dilegalisir. Sedangkan persyaratan lainnya yang membutuhkan biaya, seperti surat keterangan sehat, surat keterangan berkelakuan baik, dan surat keterangan pencari kerja, diserahkan setelah pelamardinyatakanlulus atau diterima. Dengan metode yang demikian, maka pelamar dapat mengurangi biaya dan jumlah persyaratan yang harus diverifikasi oleh panitia lebih sedikit yang sudah barang tentu menemukan efisiensi biaya petugas atautenaga administrator.

Proses pengembangan PNS belum menunjukkan efisiensi yang maksimal. Hal ini disebabkan oleh belum berjalannya sistem informasi kepegawaian (Simpeg). Program ini sesungguhnya sangat membantu setiap pegawai dalam pengurusan kepangkatan dan keperluan lainnya. Namun Simpeg baru dimulai tahun anggaran 2011 dan program ini sedang dalam tahap pembuatan oleh Badan Kepegawaian Daerah. Akibat belum berfungsinya Simpeg, pengurusan kepangkatan dan karier pegawai selama ini dilakukan secara manual 
sehingga memerlukan jalur birokrasi panjang dan akibatnya menjadi tidak efisien.

\section{b. Transparansi}

Sebagaimana dijelaskan pada bagian depan, yang dimaksud dengan transparansi adalah penyediaan informasi tentang pemerintah(an) bagi publik dan dijaminnya kemudahan di dalam memperoleh informasi yang akurat dan memadai.Dalam usaha memberikan informasi kepada masyarakat tentang rekrutmen PNS Badan Kepegawaian Daerah melakukan kerjasama dengan media cetak maupun media elektronik. Disamping itu informasi penerimaan PNS disebarkan di setiap instansi pemerintah, seperti seluruh kantor Satuan Kerja Perangkat Daerah (SKPD), Kecamatan, dan Desa atau Kelurahan. Penyebaran informasi dengan cara tersebut dimaksudkan untuk membuka informasi akses sebesar-besarnya kepada masyarakat.

Kondisi geografis Lombok Tengah dimana jarak antara ibu kota kecamatan dengan desa yang relatif dekat menyebabkan informasi lebih mudah sampai kepada msyarakat meskipun hanya melalui pengumuman di kantor-kantor pemerintah. Namun demikian, karena penyebaran informasi penerimaan PNS tidak memanfaatkan elektronik seperti internet, menyebabkan informasi tersebut sulit mendapatkan akses oleh masyarakat dari luar daerah. Kesulitan akses informasi oleh masyarakat dari luar daerah juga disebabkan oleh penggunaan media massa yang terbatas pada media massa lokal.

Pada sisi pengembangan pegawai, aspek transparansi belum terlaksana dengan baik. Kondisi ini disebabkan oleh dua faktor, yakni faktor politik dan faktor teknis. Pada faktor politik bekerja dua situasi; kurang adanya kemauan politik dari pimpinan eksekutif danDPRDterhadapkebijakan pengembangan pegawai, dan tingginya kepentingan politik dalam pengisian jabatan-jabatan struktural. Sedangkan pada faktor teknis, ditemukan tiga penyebab utama, yakni; ketersediaan tenaga analis jabatan kurang memadai, anggaran yang rendah, dan belum terlaksananya Simpeg.

Dalam usaha membangun transparansi pengembangan PNS, Pemerintah Daerah sejak tahun 2011 mulai melaksanakan uji kelayakan dan kepatutan untuk calon pejabat pada semua tingkatan jabatan. Sampai dengan penelitian ini dilaksanakan telah berlangsung dua tahap uji kelayakan dan kepatutan PNS; pertama dilaksanakan untuk calon pejabatan struktural pada pegawai administrasi, kedua dilaksanakan untuk calon Kepala Sekolah baik SD, SMP, maupun SMA. Namun demikian, hasil akhir atau nilai dari proses tersebut tidak diumumkan kepada publik, sehingga masyarakat menilai kurang transparan.

\section{c. Kesetaraan}

Konsep kesetaraan dalam good governance dirumuskan sebagai 
adanya peluang yang sama bagi setiap anggota masyarakat untuk beraktivitas atau berusaha. Peneliti menterjemahkan rumusan tersebut sebagai konsep setiap warga negara indonesia memiliki hak yang sama secara setara untuk menjadi pegawai negeri sipil, serta mendapat hak yang sama dan setara dalam mendapatkan karier. Praktek kesetaraan dalam rekrutmen pegawai Kabupaten Lombok Tengah sejak tahun 2010 sudah mengalami kemajuan. Hal ini terlihat dari diberikannya kesempatan yang sama kepada semua warga negara untuk mengajuan lamaran dan mengikuti seleksi tanpa melihat asal daerah. Kesetaraan ini terlihat dari tidak mencantumkan Kartu Tandari Penduduk (KTP) Lombok Tengah dalam persyaratan pendaftaran calon pegawai.

Apabila dalam rekrutmen PNS memperhatikanaspekkesetaraan,tidak demikian halnya pada pengembangan PNS. Salah satu bentuk ketidaksetaraan pengembangan pegawai di Kabupaten Lombok Tengah adalah posisi PNS perempuan. Dari seluruh dinas di Kabupaten Lombok Tengah hanya terdapat 1 (satu) Kepala Dinas dari kaum perempuan, yakni Kepala Dinas Kependudukan dan Catatan Sipil. Sedangkan dari 12 (dua belas) jabatan Camat, hanya 1 (satu) Camat perempuan yakni Camat Pringgarata. Kondisi demikan kontradiksi dengan dokumen visi, misi, dan program Bupati dan Wakil Bupati yang salah satunya menyebutkan kesetaraan gender dalam birokrasi.

\section{Permasalahan dan Solusi Kebijakan}

a. Permasalahan

Good governance sebagai pendekatan pembangunan birokrasi, lebih merupakan nilai atau budaya yang memiliki cita-cita menjadikan birokrasi yang baik. Ia belum memiliki ukuran-ukuran yang lebih operional dan teknis. Sebagai nilai dan budaya praktek good governance dalam rekrutmen dan pengembangan PNS ditemukan dua permasalahan sebagai berikut:

1. Permasalahan Regulasi

Administrasi kepegawaian Republik Indonesia menganut merit system (sistem keahlian) mengharuskan para pemegang jabatan profesional pada jabatan eselon satu ke bawah serta jabatan fungsional yang setara harus bebas dari representasi partai politik dan intervensi politik Bupati/Wali Kota. Guna melaksanakan sistem tersebut seharusnya ada demarkasi yang jelas dalam pembinaan jabatan politik dan pembinaan jabatan karir. Karena itu yang seharusnya ditetapkan sebagai pembina kepegawaian adalah PNS yang paling senior di instansi daerah, yakni Sekretaris Daerah (Sekda).

Permasalahannya adalah

Peraturan Pemerintah Nomor 
96 tahun 2000 tidak mengikuti garis demarkasi tersebut karena yang memegang wewenang pengangkatan PNS adalah pejabat politik yakni Bupati. Akibat pengaburan batas demarkasi jabatan politik dan jabatan karir ini politisasi birokrasi dan praktek "spoils system" (penempatan konco atau teman, keluarga, dan kerabat yang sealiran politik dan memiliki andil dalam pemenangan Bupati dalam pemilu dalam jabatan kunci di birokrasi) tumbuh subur.

Peraturan Pemerintah Nomor 96 tahun 2000 juga memberi kewenangan mutlak terhadap Bupati untuk menetapkan kenaikan pangkat PNS Daerah, mulai dari Golongan I/b sampai Pembina Utama IV/e. Dalam penetapan kenaikan pangkat ini bahkan Gubernur dan Bupati lebih besar kewenangannya dari Presiden, karena Presiden perlu mendapat pertimbangan teknis dari Kepala Badan Kepegawaian Negara (BKN) untukpengangkatan PNS ke golongan IV/c sampai $\mathrm{IV} / \mathrm{e}$, sedangkan Gubernur dan Bupati dapat melakukan tanpa pertimbangan siapapun. Akibat kelonggaran yang amat besar ini terjadi inflasi kepangkatan PNS daerah, akhirnya membawa dampak negatif terhadap mobilitas PNS, karena bertambah kuat untuk menolak PNS daerah untuk diterima di instansi propinsi atau instansi nasional.

\section{Permasalahan In-Efisiensi}

Formasi PNS adalah instrumen pengendali yang efektif untuk menjaga agar jumlah PNS tetap berada dalam batas-batas keuangan negara serta kesehatan organisasi. Undag-Undang Nomor 33 Tahun 2004 tentang Perimbangan Keuangan Antara Pemerintah Pusat Dan Pemerintah Daerah menetapkan bahwa belanja pegawai di tanggung oleh Pemerintah Pusat dan disalurkan kepada Daerah melalui Dana Alokasi Umum (DAU).

Berdasarkan jumlah PNS Kabupaten Lombok Tengah sebanyak 11.107 orang, anggaran yang dihabiskan mencapai Rp.591.061.194 dari total belanja tidak langsung sebesar Rp.680.731.496. Disisi yang lain, Pemerintah Daerah belum memiliki kemampuan untuk memberikan gaji pegawai secara mandiri, maka segala pembiayaan gaji pegawai dibebankan kepada pemerintah pusat (APBN) melalui dana alokasi umum (DAU). Berdasarkan hal tersebut penelitian ini mengemukakan penerimaan PNS di Kabupaten Lombok Tengah sudah tidak lagi memenuhi ketentuan efisiensi. Hal ini sudah barang tentu menjadi ruang munculnya kerugian negara. 
b. Solusi

Berdasarkan permasalahan di atas, penelitian ini menemukan solusi sebagai berikut;

1. Diperlukan deregulasi terkait pengangkatan, pemindahan, dan pemberhentian PNS

- Kewenangan yang diberikan Bupati berdasarkan Peraturan Pemerintah Nomor 96 tahun 2000 terlalu besar, yang berakibat pada praktekpraktek spoils system dan politisasi birokrasi. Untuk itu peraturan tersebut perlu dilakukan perubahan, dimana kewenangan pengangkatan, pemindahan, dan pemberhentian PNS daerah cukup menjadi kewenangan Sekretaris Daerah (Sekda).

- Mengoreksi penyimpanganpenyimpangan terhadap asumsi sistem kepegawaian meritokratik dengan mengeluarkan suatu Peraturan Bupatiyangmengaturprosudur pelaksanaan wewenang pengangkatan, pemindahan, dan pemberhentian PNS, formasi pengadaan, kenaikan pangkat dan pengangkatan padajabatanstrukturalmaupun jabatan fungsional.

2. Diperlukan azas efisiensi dalam rekrutmen PNS

Oleh karena biaya pegawai daerah masih bersumber dari Anggaran
Pendapatan Dan Belanja Negara (APBN), maka agar belanja pegawai tidak melebihi kemampuan anggaran, formasi penerimaan CPNS setiap tahun sebaiknya mempertimbangkan beban kerja dan kemampuan keuangan pemerintah. Disamping itu agar biaya yang dikeluarkan oleh pelamar CPNS mapun PNS yang ingin mengembangkan karir lebih efisien dapat melakukan tiga langkah konkrit, yakni; administratif, pengurangan biaya, dan adopsi teknologi.

Bidang administrasi yang penting diperbaiki antara lain; (1) menyederhanakan formulir, (2) mengumumkan secara terbuka semua persyaratan dan prosudur dengan cara; menempelkan pada papan pengumuman, mengumumkan melalui radio, $\mathrm{TV}$, dll, membuat web site, (3) mengoptimalkan penggunaan teknologi internet, sehingga tidak sekedar menampilkan data atau informasi saja, tetapi melengkapinya dengan fasilitas download untuk mendapatkan semua formulir. Adapun strategi pengurangan biaya antara lain; (1) membebaskan biaya yang bersifat mendasar, (2) membangun kerjasama untuk beasiswa, (3) pengiriman pendidikan PNS berdasarkan kebutuhan organisasi. Sedangkan strategi mengadobsi teknologi yaitu mengoptimalkan penggunaan teknologi komputer dan informasi. Beberapa hal yang dapat dilakukan antara lain; (1) mengembangkan data base serta mengaplikasikan proses administrasi dan manajemen 
melalui sistem komputer online, (2) penggunaan website untuk proses pengadministrasian, (3) perlu mempertajam kembali test kompetensi dan psiko test. Kemudian khsus PNS fungsional (guru, tenaga penyuluh,) memerlukan test tambahan.

\section{E. Kesimpulan}

1. Jumlah PNS Lombok Tengah sampai penelitian ini dibuat 11.107 orang dengan permasalahan kuantitas dan kualitas pendidikan tidak proporsional dengan bidang pekerjaan

2. Sistem rekrutmen masih ansih merujuk pada PP Nomor 98 tahun 2000 tanpa dijelaskan lebih teknis dalam Peraturan Bupati

3. Nilai-nilai good governance secara jamak telah diterapkan pada tahapan rekrutmen tetapi tidak ditemukan pada tahap pengembangan PNS, yang dilihat dari dilaksanakannya dengan baik prinsip efisiensi, transparansi, dan kesetaraan

4. Berdasarkan lemahnya praktek good governance dalam pengembangan PNS, penelitian ini mermuskan solusi kebijakan sebagai berikut:

a. Deregulasi

kewenangan

terhadap

sebagaimana di atur dalam

PP Nomor 96 tahun 2000, kewenangan pengangkatan, pemindahan, dan pemberhentian PNS menjadi kewenangan Sekretaris Daerah sebagai eselon tertinggi di daerah tidak lagi kewenangan Bupati.

b. Diperlukan adanya peraturan teknis berbentuk Peraturan Bupati tentang pengangkatan, pemindahan, dan pemberhentian PNS sebagai garis-garis umum kebijakan.

c. Pada waktu bersamaan asasasas good governance tidak hanya berhenti menjadi nilai universal dalam kebijakan kepegawaian, tetapi memerlukan rumusan yang lebih teknis dan implementatif

\section{Daftar Pustaka}

Dwiyanto, Agus, 2008, Mewujudkan Good Governance Melalui Pelayanan Publik, diterbitkan oleh Gadjah Mada University Press

Syafi $i$, Kencana Inu, 2003, Sistem administrasi Negara Republik Indonesia, diterbitkan oleh PT. Bumi Aksara, Jakarta

Nawawi, 2007, Metode Penelitian Bidang Sosial, diterbitkan oleh Gadjah Mada University Press

Nugroho, Riant, 2008, Public Policy, diterbitkan oleh PT.Elex Media Komputindo-Jakarta

Mas`ud,M.Said, 2007, Birokrasi Di Negara Birokratis, diterbitkan oleh UMM Press 
Sandu Wasistiono, 2002, Manajemen Sumber Daya Aparatur Daerah, Fokusmedia-Bandung-Anggota IKAPI

Weber, Max, 1946, Sociology, diIndonesikan oleh Noorkholis, 2006, diterbitkan oleh Pustaka Pelajar

Sugiyono, 2011, Metode Penelitian Kuantitatif Kualitatif Dan R \& D, diterbitkan oleh ALFABETA

\section{Bacaan Lain:}

Pemerintah Kabupaten Lombok Tengah tahun 2011, Rancangan Awal Rencana Pembangunan Jangka Menengah Daerah (RPJMD) Kabupaten Lombok
Tengah Tahun 2011-2015, tidak diterbitkan.

Undang-Undang Republik Indonesi Nomor 43 tahun 1999 tentang Pokok-Pokok Kepegawaian

Undang-Undang Republik Indonesia Nomor 32 tahun 2004 tentang Pemerintah Daerah

Undang-Undang Republik Indonesia Nomor 33 tahun 2004 tentang Perimbangan Keuangan Antara Pemerintah Pusat Dan Pemerintah Daerah

Undang-Undang Republik Indonesia Nomor 17 tahun 2007 tentang Rencana Pembangunan jangka Panjang Nasional (RPJPN) 20052025 